\title{
Psycho-Semantic Analysis of Individual Structure of Adolescent's World Image
}

\author{
Elizaveta I. Shuleva ${ }^{1 *}$ \\ Nosov Magnitogorsk State Technical University, 26, Lenin Avenue, 455000 Magnitogorsk, Russia
}

\begin{abstract}
The article presents the results of an empirical study of the structure of the image of the older adolescent's world. When analyzing the data, the computer program of statistical analysis of texts "ADVEGO", content analysis, morphological and semantic analysis was used. Morphological analysis of empirical data has shown that the most used words belong to the category of nouns. Content analysis made it possible to identify eight semantic categories of word groups that characterize the levels of the image of the teenager's world: nature, social, subject, friendship, school, hobbies and leisure, family, mental (needs, cognitive processes, emotions, feelings, personal qualities). The most significant level in terms of the volume of semantic units and the nature of ongoing processes is the mental level. The results of the conducted research allowed drawing the following conclusions. The individual structure of an older adolescent's world image is a complex mental phenomenon that has universal, age and individual characteristics. Its universal characteristics are multi-levelness and hierarchy; age-related - dynamics, polarity, existentialism, and accentuation on the present time. The individual characteristics of an older adolescent's world image are due to individual personal characteristics of the flow of his or her mental activity.
\end{abstract}

\section{Introduction}

The modern social situation increasingly demonstrates instances of deviant behavior of adolescents in all its forms. News broadcasts more and more often report such cases of adolescents' behavior which Russian society has not previously encountered. When analyzing the facts presented by the media and the commentaries thereto both of the general public and of professionals working with adolescents, there is a steady sense of confusion and misunderstanding of the situation. It should also be noted that the basic research of adolescence was conducted during the Soviet period of the development of our society, when the social situation was significantly different from today's reality. The study of modern adolescents' perception of the world around them and the characteristics of the formation of their inner world allowed a closer understanding of the causes of deviations in behavior

\subsection{Relevance and backgrounds}

The studies of the problem of the world image in homeland psychology have been carried out by A.N. Leontiev [1], S.D. Smirnov [2], V.V. Petukhov [3], F.E. Vasilyuk [4], O.E. Baksanskiy, and E.N. Kucher [5]. The peculiarities of its structure, functions and formation were studied by O.V. Glushenkov [6], M.V. Kartavenko [7], and V.P. Serkin [8]. The main aspects of the psychosemantics of the world image are presented in the works of A.A. Leontiev [9], E.Y. Artemyeva [10], V.V. Stolin, M. Calvinho, A.N. Naminach [11, 12], and G.V. Kolshanskiy [13]. The problem of the world image of adolescents is actively and diversely developed by modern domestic psychologists. The biosocial determinants of the semantic organization of the world image of adolescents are described by the researchers A.N. Alekhin, N.N. Koroleva, I.M. Bogdanovskaya, and V.F. Lugovaya [14].

The concepts of co-evolution of the nature and society in the formation of the world image of adolescents are studied by A.V. Kiriakova, and I.A. Silkina [15]. The semantic features of the world image of adolescents are in the field of scientific interests of I.A. Burovikhina [16], E.I. Shuleva [17]. O.A. Bogpomocheva [18], M.V. Musiychuk [19] study the problems of creativity development and the peculiarities of the world image of gifted adolescents, and M.V. Miroshnichenko [20] studies the features of the world image of deviant adolescents. The world image of adolescents from incomplete families is studied by W.W. Gazizova, R.F. Habibrahmanova, and O.M. Shterz [21], M.A. Odintsova [22]. The role of the information and communication environment and the peculiarities of the system of attitudes to oneself and to the surrounding world in the formation of the world image of adolescents are analyzed by I.M. Bogdanovskaya, G.Yu. Ikonnikova, N.N. Koroleva [23], E.I. Shuleva [24]. Adolescents' subjective image of the social world is studied by I.A. Nikolaeva [25]. The idea of aggressive behavior in the

* Corresponding author: lizunova07@ rambler.ru 
structure of the world image of adolescents is described by O.V. Chursinova [26]. The field of scientific interests of V.V. Goryachev [27] is the image of the body in the structure of the image of the world. A generalized analysis of the main theoretical approaches to the study of the world image in adolescence is presented by K.V. Bobrovskaya [28].

The analysis of the literature showed a fairly high level of interest of scientists in the selected issue; however, the studies of the image of the world using the methods of psycholinguistics failed to be established.

The system of semantic values can be investigated by studying the products of speech activity, because: "... speech, word have a semantic, meaning content..." [29, p. 386]. Revealing the psychological nature of speech, Rubinstein stresses the existence of the correlation of speech, language, and consciousness. In the article "Psychology of the Image", Leontiev notes: "Addressing... the consciousness of man, I have to introduce another concept - the concept of the fifth quasi-dimension, which opens to man the objective world. This is the semantic field, the system of values (italics of the author) in which an objective world is opened to a person" [9, p. 253]. The study of adolescents' world image involves understanding the "system of values", which involves the use of psycholinguistic methods.

\subsection{Purpose}

The purpose is to study the individual structure of an older adolescent's world image.

\subsection{Methods}

The study applied the method of "unfinished sentences". In the analysis of the data, the computer program for statistical analysis of texts "ADVEGO", content analysis, morphological and semantic analyses were used.

\section{Discussion}

Table 1 presents the results of the overall statistical analysis of the entire lexical material.

Characterizing the category of "My image of the world", adolescents quite clearly differentiate and describe the individual image of the world. The statistical analysis of empirical data showed that most words used by them $(90.49 \%)$ belong to the category of nouns (Table 1).

The obtained data were subjected to content analysis, the semantic units of which were all the participants' responses written in the course of the study (Table 2).

The analysis showed that the aggregate volume of duplicated (from 25 to 3 times) semantic units is 17.53 $\%$. Table 3 presents 20 semantic units, most frequently used by adolescents.
Table 1. The results of statistical analysis.

\begin{tabular}{|c|c|c|c|c|}
\hline \multirow[b]{2}{*}{$\begin{array}{l}\text { The object } \\
\text { of study }\end{array}$} & \multirow[b]{2}{*}{ No. } & \multirow[b]{2}{*}{ Indicator } & \multicolumn{2}{|c|}{$\begin{array}{l}\text { My image of the } \\
\text { world }\end{array}$} \\
\hline & & & $\begin{array}{c}\text { the } \\
\text { number, } \\
n\end{array}$ & $\begin{array}{c}\text { share in } \\
\text { total } \\
\text { volume, } \\
\%\end{array}$ \\
\hline \multirow{10}{*}{$\begin{array}{l}\text { The entire } \\
\text { volume of } \\
\text { responses }\end{array}$} & 1 & $\begin{array}{l}\text { The number of } \\
\text { words }\end{array}$ & 357 & 100.00 \\
\hline & 2 & $\begin{array}{l}\text { The number of } \\
\text { unique words }\end{array}$ & 162 & 45.38 \\
\hline & 3 & $\begin{array}{l}\text { The number of } \\
\text { significant words }\end{array}$ & 105 & 29.91 \\
\hline & 4 & $\begin{array}{l}\text { The semantic } \\
\text { core }\end{array}$ & 323 & 90.49 \\
\hline & 5 & $\begin{array}{l}\text { Nouns (with } \\
\text { repetitions) }\end{array}$ & 131 & 40.56 \\
\hline & 6 & $\begin{array}{l}\text { Nouns (without } \\
\text { repetitions) }\end{array}$ & 13 & 3.64 \\
\hline & 7 & Adjectives & 8 & 2.24 \\
\hline & 8 & Verbs & 7 & 1.96 \\
\hline & 9 & Adverbs & 6 & 1.68 \\
\hline & 10 & Pronouns & 46 & 12.89 \\
\hline
\end{tabular}

Table 2. The results of the content analysis of units of meaning (nouns).

\begin{tabular}{|c|c|c|c|c|}
\hline No. & $\begin{array}{c}\text { The } \\
\text { number } \\
\text { of units } \\
\text { of } \\
\text { meaning, } \\
\mathrm{n}\end{array}$ & $\begin{array}{c}\text { The frequency } \\
\text { of repetition } \\
\text { of semantic } \\
\text { units, } \mathrm{n}\end{array}$ & $\begin{array}{c}\text { The share } \\
\text { of } \\
\text { semantic } \\
\text { units, } \\
\text { in total } \\
\text { volume, } \%\end{array}$ & $\begin{array}{c}\text { The share } \\
\text { of } \\
\text { semantic } \\
\text { units } \\
\text { in the } \\
\text { volume } \\
\text { of } \\
\text { nouns, } \%\end{array}$ \\
\hline 1 & 1 & 25 & 6.98 & 0.76 \\
\hline 2 & 1 & 24 & 6.70 & 0.76 \\
\hline 3 & 1 & 13 & 3.63 & 0.76 \\
\hline 4 & 1 & 11 & 3.07 & 0.76 \\
\hline 5 & 1 & 10 & 2.79 & 0.76 \\
\hline 6 & 2 & 9 & 5.02 & 1.53 \\
\hline 7 & 1 & 8 & 2.23 & 0.76 \\
\hline 8 & 1 & 7 & 1.96 & 0.76 \\
\hline 9 & 5 & 6 & 8.40 & 3.81 \\
\hline 10 & 2 & 5 & 2.80 & 1.53 \\
\hline 11 & 4 & 4 & 4.48 & 3.05 \\
\hline 12 & 3 & 3 & 2.52 & 2.29 \\
\hline 13 & 21 & 2 & 11.76 & 16.03 \\
\hline 14 & 87 & 1 & 24.36 & 66.41 \\
\hline
\end{tabular}

The analysis showed that the aggregate volume of duplicated (from 25 to 3 times) semantic units is $17.53 \%$. Table 3 presents 20 semantic units, most frequently used by adolescents. 
Table 3. Semantic units, selected on the basis of content analysis (max. frequency).

\begin{tabular}{|c|c|c|c|c|}
\hline \multirow[b]{2}{*}{$\begin{array}{l}\text { The object } \\
\text { of study }\end{array}$} & \multirow[b]{2}{*}{ No. } & \multicolumn{3}{|c|}{ My image of the world } \\
\hline & & $\begin{array}{c}\text { Semantic } \\
\text { unit }\end{array}$ & $\begin{array}{c}\text { the } \\
\text { number, } \mathrm{n}\end{array}$ & $\begin{array}{c}\text { share in } \\
\text { total } \\
\text { volume, } \%\end{array}$ \\
\hline \multirow{20}{*}{$\begin{array}{l}\text { The entire } \\
\text { volume of } \\
\text { responses }\end{array}$} & 1 & friend & 25 & 6.98 \\
\hline & 2 & family & 24 & 6.70 \\
\hline & 3 & school & 13 & 3.63 \\
\hline & 4 & life & 11 & 3.07 \\
\hline & 5 & study & 10 & 2.79 \\
\hline & 6 & Internet & 9 & 2.51 \\
\hline & 7 & house & 9 & 2.51 \\
\hline & 8 & love & 8 & 2.23 \\
\hline & 9 & training & 7 & 1.96 \\
\hline & 10 & telephone & 6 & 1.68 \\
\hline & 11 & sadness & 6 & 1.68 \\
\hline & 12 & fun & 6 & 1.68 \\
\hline & 13 & street & 6 & 1.68 \\
\hline & 14 & book & 6 & 1.68 \\
\hline & 15 & music & 5 & 1.40 \\
\hline & 16 & animal & 5 & 1.40 \\
\hline & 17 & parent & 4 & 1.12 \\
\hline & 18 & sports & 4 & 1.12 \\
\hline & 19 & relative & 4 & 1.12 \\
\hline & 20 & joy & 4 & 1.12 \\
\hline
\end{tabular}

The results are clearly shown in figure 1 .

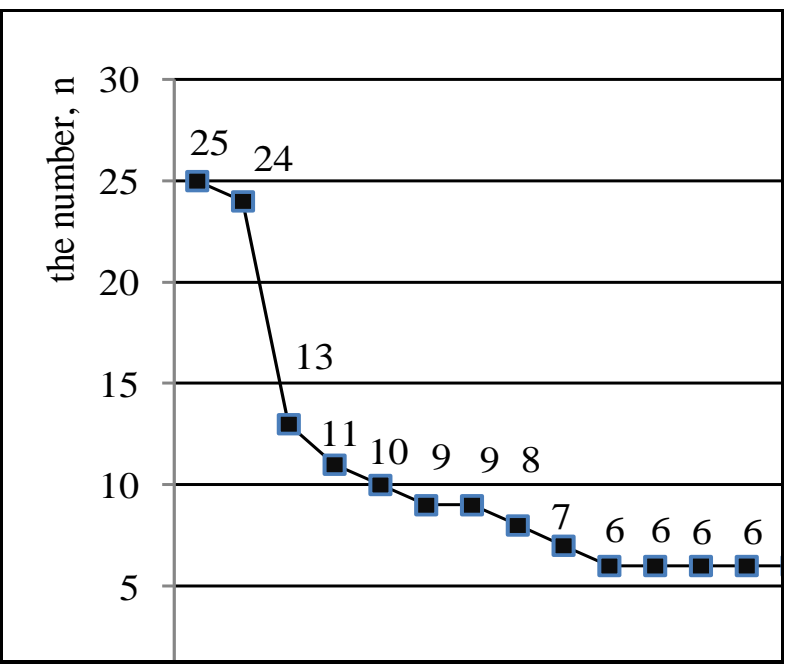

Fig. 1. Semantic units, selected on the basis of content analysis (max. frequency).

The semantic analysis of semantic units reveals the characteristics of the image of the world typical for modern adolescents. It is a life in which an adolescent is surrounded by friends, relatives, pets and is busy by socially-approved activities: communication, studies, and sports. He or she has a rest, walks outside, listens to the music, and reads books. The basic range of emotions includes fun, joy and sometimes sadness.
Content analysis allowed identifying 109 semantic units - nouns with the frequency of repetitions 1-2 times, which amounted to $67.28 \%$ of the total volume of all semantic units and $83.21 \%$ of the volume of nouns. They reveal the individual characteristics of an adolescent's world image. For a better understanding of the semantic meaning of the semantic units, their classification by the main types of nouns (Table 4) was carried out.

Table 4. The classification of semantic units - nouns.

\begin{tabular}{|l|c|c|}
\hline \multirow{2}{*}{ Types of nouns } & \multicolumn{2}{|c|}{ My image of the world } \\
\cline { 2 - 3 } & $\begin{array}{c}\text { The frequency of } \\
\text { repetition of } \\
\text { semantic units, } \mathrm{n}\end{array}$ & $\begin{array}{c}\text { The share of } \\
\text { semantic units, } \\
\text { in total volume, } \%\end{array}$ \\
\hline $\begin{array}{l}\text { Nouns (without } \\
\text { repetitions) }\end{array}$ & 131 & 40.56 \\
\hline Specific & 52 & 39.69 \\
\hline $\begin{array}{l}\text { Unrelated } \\
\text { (abstract) }\end{array}$ & 62 & 47.33 \\
\hline Collective & 5 & 3.82 \\
\hline Material & 3 & 2.29 \\
\hline $\begin{array}{l}\text { Single } \\
\text { (singulative) }\end{array}$ & 0 & 0 \\
\hline
\end{tabular}

The results show that the most frequently used are specific $(39.69 \%)$ and abstract nouns $(47.33 \%)$. Their ratio characterizes the age peculiarities of the mental development of adolescents: the gradual transition from visual-figurative to abstract-logical thinking.

The concrete nouns reveal the objective world of an adolescent, the abstract ones "... denote an action or characteristic in the derivation from an action or the carrier of the trait..." [30, p. 125]. The analysis of abstract semantic units reveals deeper levels of the image of the world. In the minds of adolescents, the semantic units are present which are ethical (happiness, freedom, goodness) and aesthetic categories (beauty). Derived abstract nouns form antonymous pairs describing the characteristics of adolescents (study - game, work rest); their emotional life (sadness - joy, love jealousy); the dynamics of the development of consciousness (light - darkness, life - death). The analysis of the results reveals the process of creating an individual system of values (happiness, freedom, friendship, love, work) of adolescents. The obtained data also contain semantic units characterizing modern adolescents' values: popularity, fashion, and music.

Abstract semantic units with the characteristic of action reveal the principal activities of adolescents: communication, learning, leisure, work. The peculiarities of their dynamics are also represented by antonymous pairs: calm - activity, study - games, labour - leisure, work - entertainment.

Single recurring semantic units reveal an individual world of the person gradually getting to know his or her 
capabilities including drawing, music, technology, development, imagination, creativity.

The content analysis revealed 13 adjectives $(3.36 \%$ of the total share). One of them is relative, pointing to the place (home), and the rest are qualitative (personal, pure, lovely, best, interesting, interesting, vital, challenging, strange, independent) characterizing the feature of the subject. The semantic meanings of qualitative adjectives reveal intimacy, purity, beauty, mobility, inconsistency and self-sufficiency of an adolescent's world image.

The content analysis revealed in the responses of adolescents 8 verbs that made $2.24 \%$ of the total share (Table 5).

Table 5. The results of the content analysis of semantic units verbs.

\begin{tabular}{|c|c|c|c|}
\hline No. & $\begin{array}{c}\text { Semantic } \\
\text { unit }\end{array}$ & $\begin{array}{l}\text { The meaning of } \\
\text { the semantic unit } \\
\text { (verb) }\end{array}$ & $\begin{array}{l}\text { The frequency of } \\
\text { repetition of } \\
\text { semantic units, } n\end{array}$ \\
\hline 1 & to fool & specific action & 1 \\
\hline 2 & to go & \multirow{2}{*}{$\begin{array}{l}\text { movement and } \\
\text { transfer in space }\end{array}$} & 1 \\
\hline 3 & to walk & & 1 \\
\hline 4 & to live & \multirow{3}{*}{$\begin{array}{l}\text { physical } \\
\text { condition }\end{array}$} & 1 \\
\hline 5 & to gobble & & 1 \\
\hline 6 & to sleep & & 1 \\
\hline 7 & to like & mental state & 1 \\
\hline 8 & see & $\begin{array}{l}\text { the activities of } \\
\text { the sense organs }\end{array}$ & 1 \\
\hline
\end{tabular}

The semantic characteristic of the verb is the designation of the action or state as a process. The verbs used by the respondents have the forms the present (see, like) and the indefinite (infinitive) tense: to live, to gobble, to sleep, to walk, to go, to fool.

This amount is too little for active adolescents, which indicates the existing limitation of opportunities for activities. The adolescents describe their activities using not verbs but abstract nouns with the sign of action. This feature indicates the presence of the social derivation of adolescents. They are ready to become more active in social activities, but the analysis of lexical units indicates their absence. The infantile family-school-sports environment is insufficient for a full mental development of an older adolescent. The needs of adolescents in independent activity and bright emotions, facing the external restrictions of their implementation, can be transformed into internal contradictions, reflected in their aggressive behavior.

The content analysis allowed identifying eight semantic categories of groups of words characterizing the levels of an adolescent's world image: nature, social, subject, friendship, school, hobbies and leisure, family, mental (needs, cognitive processes, emotions, feelings, personal qualities). The most substantial in terms of the volume of semantic units and the nature of processes is the mental level. It is the "boiling point", "volcano" of an adolescent's world image.

\subsection{Conclusions}

The results of the conducted research allowed drawing the following conclusions:

The individual structure of an older adolescent's world image is a complex mental phenomenon that has universal, age and individual characteristics. Its universal characteristics are multi-levelness and hierarchy; agerelated - dynamics, polarity, existentialism, and accentuation on the present time. The individual characteristics of an older adolescent's world image are due to individual personal characteristics of the flow of his or her mental activity.

\subsection{Application}

The results obtained supplement the knowledge about the individual and personal features of functioning and formation of the image of the world in adolescence. They can be used in psychological and pedagogical work with adolescents in prediction and correction of the individual trajectory of their development and creation of a psychologically safe environment. The procedure of objectifying the image of the world allows a teenager to be aware of his/her problems, contributes to the development of internal regulation of the individual perceptions of reality and correction of non-constructive ways of behavior.

\section{References}

1. A.N. Leontiev, The Image of the World. In A.N. Leontiev, Selected Psychological Works: In 2 Volumes (Moscow, Academy of Pedagogical Sciences, 1983)

2. S.D. Smirnov, Theory and methodology of psychology. Post-Nonclassical Perspective (Moscow, Russian Academy of Sciences, Institute of Psychology, 2007)

3. V.V. Petukhov, Bulletin of MGU, Series 14, Psychology 4, 13 (1984)

4. F.M. Vasilyuk, Psychological Journal 3, 90 (1995)

5. O.E. Baksanskiy, E.N Kucher, Problems of Philosophy 8, 52 (2002).

6. O.V. Glushenkov, Problems of Humanities 4(31), 29 (2007)

7. M.V. Kartavenko, News of SFedU. Engineering Sciences 13(68), 234 (2006)

8. V.P. Serkin, Bulletin of Moscow University. Series 14: Psychology 1, 11 (2006)

9. A.A. Leontiev, Psychological Structure of Meaning. Semantic Structure of the Word (Moscow, Nauka, 1971)

10. E.Y. Artemieva, Bulletin of MGU, Series 14, Psychology 1, 61 (1991)

11. V.V. Stolin, M. Calvino, Bulletin of MGU 3 (1983)

12. V.V. Stolin, A.N. Naminach, Problems of Psychology 4, 34 (1988)

13. G.V. Kolshanskiy, Objective Picture of the World in Cognition and Language (Moscow, Flinta, 2012) 
14. A.N. Alekhin, N.N. Koroleva, I.M. Bogdanovskaya, V.F. Lugovaya, Psychology, Sociology and Pedagogy 11(38), 100-106 (2014)

15. A.V. Kiriakova, I.A. Silkina, The Emissia. Offline Letters 2, 1967 (2013)

16. I.A. Burovikhina, Bulletin of the University (State University of Management) 14, 16 (2011)

17. E.I. Shuleva, Society: Sociology, Psychology, Pedagogy 11, 103-105 (2017)

18. O.A. Bogpomocheva, Psychological Science and Education 4, 5-22 (2006)

19. M.V. Musiychuk, Psychological and Pedagogical Support of Preschool and General School Education, 65-85 (2015)

20. M.V. Miroshnichenko, Psychology of Education 9, 43-54 (2012)

21. U.V. Gazizova, R.F. Habibrakhmanova, O.M. Shterz, Modern High Technology 7-2, 201-202 (2013)

22. M.A. Odintsova, Problems of Psychology 2, 82-89 (2011)

23. I.M. Bogdanovskaya, G.Y. Ikonnikova, N.N. Koroleva, Psychological and Pedagogical Research 7(1), 1-11 (2015)

24. E.I. Shuleva, World of Science 5 (6), 93. (2017)

25. I.A. Nikolaeva, The Subjective Image of the Social World as a Representation of the Social Situation of Development of the Individual (on the Example of Adolescence) (Ph.D. Thesis) (Kurgan, 2004)

26. O.V. Chursinova, North-Caucasus Humanitarian Institute Bulletin 4, 261-266 (2014)

27. V.V. Goryachev, Physical Education and Health 1(43), 32-36 (2013)

28. K.V. Bobrovskaya, Relevant Problems of the Humanities and Natural Sciences 10-2, 276 (2013)

29. S.L. Rubinstein, Fundamentals of General Psychology (St. Petersburg, Piter, 2002).

30. D.E. Rosenthal, M.A. Telenkova, DictionaryReference of Language Terms (Moscow, Prosveshchenie, 1976). 